\title{
Parental roles of male and female thick-billed murres and razorbills at the Gannet Islands, Labrador
}

\author{
Rosana Paredes $^{1,2)}$, Ian L. Jones ${ }^{1)}$ \& Daryl J. Boness ${ }^{3,4)}$ \\ $\left({ }^{1}\right.$ Department of Biology, Memorial University of Newfoundland, Canada; ${ }^{3}$ Conservation \\ and Research Centre, National Zoological Park, Smithsonian Institution, Washington, DC, \\ USA)
}

(Accepted: 4 January 2006)

\begin{abstract}
Summary
We studied female and male parental roles in two sympatric auks, thick-billed murre (Uria lomvia) and razorbill (Alca torda), with initial biparental care at the breeding site and later exclusively paternal care at sea. Our study addressed the following two questions: Why do males accompany chicks to sea?, and How do the sexes allocate parental effort at the breeding site before parental care at sea begins? We tested the hypothesis that males care for chicks at sea because they are in better condition at the time of chick departure as a result of femalebiased parental effort at the breeding site ('nest'). Breeding success and duration of chickrearing did not differ between the two study years in either species at the Gannet Islands, Labrador. At the breeding colonies, females of both species provided more food (murres: $2.84 \pm 0.18$ loads day ${ }^{-1}$; razorbills: $2.02 \pm 0.11$ loads day ${ }^{-1}$ ) to their chicks than males (murres: $2.26 \pm 0.12$ loads day ${ }^{-1}$; razorbills: $1.42 \pm 0.09$ loads day $^{-1}$ ), and males spent more time brooding the chicks. These differences were chick-age dependent in both species, with females providing more meals to chicks older than two weeks. Razorbill males spent more time with chicks greater than two weeks old, while murre male's attentiveness of brooding did not vary with chick age. In both species, males (murres: $3.04 \pm 0.3 \mathrm{~h} \mathrm{day}^{-1}$; razorbill: $3.30 \pm 0.2 \mathrm{~h} \mathrm{day}^{-1}$ ) performed longer foraging trips with meal delivery than females (murres: $1.23 \pm 0.4 \mathrm{~h}$ /day; razorbill: $2.50 \pm 0.4 \mathrm{~h} \mathrm{day}^{-1}$ ). Thick-billed murres showed a consistent diurnal pattern of egg and chick attendance: females were usually found at the breeding site during the day whereas males were found there early in the morning and at night. In contrast, razorbill's timing of attendance was much more variable and did not differ between sexes.
\end{abstract}

2) Corresponding author's address: R. Paredes (c/o Stephen J. Insley), Long Marine Laboratory, Institute of Marine Sciences, University of California, Santa Cruz 100 Shaffer Rd, Santa Cruz CA 95060, e-mail: u92rp@mun.ca.

4) D.J. Boness is at the Conservation and Research Centre, National Zoological Park, Smithsonian Institution, 20008 Washington DC, USA and University of Maine, Orono, USA. 
Despite these differences in timing of breeding site attendance between species, males of both species spent twice as much time as females engaged in the defence of the egg or chick at the breeding site, which suggest male-biased capability of protecting the chick at departure. Overall our data indicated different female and male parental roles at the breeding site but not a female-biased allocation of time, energy and risk as predicted. In fact, males seem to provide equal if not more parental effort than females prior to the time of colony departure. We propose that the patterns of parental roles found between sexes is the result of a chain of events favouring male involvement in chick brooding and care at sea.

Keywords: parental care, seabird, alcid, chick provisioning, foraging trips, parental roles, sex.

\section{Introduction}

Decision-making about allocation of energy, time and risk is an ongoing task for animals during reproduction and it is believed that natural selection acts against individuals that fail to balance tradeoffs associated with these decisions. The allocation of resources between current and future reproduction is the crucial life-history trade-off (Williams, 1966), and long-lived species should maximize lifetime fitness by balancing current and future costs and benefits of reproduction (Stearns, 1992). In nature, excessive reproductive effort at one breeding attempt may greatly decrease individuals' lifetime reproductive success in long-lived seabirds (Croxall \& Rothery, 1991; Woller et al., 1992). In monogamous species such as seabirds, biparental care is obligatory because a lapse of one parent's contribution leads to breeding failure. Although biparental care is necessary for success in such species, the level of contribution toward specific duties, or parental roles, may vary between sexes (Trivers, 1972; Bart \& Tornes, 1989).

The members of the avian family Alcidae are a diverse group of diving birds with remarkably variable forms of parental care and stages of chick development at the time of chick departure from the breeding site. At one end of the spectrum, puffins (Fratercula sp.), guillemots (Cepphus sp.) and Brachyramphus murrelets provide biparental care at the nest site until chicks are nearly fully grown ('semi-precocial'; Sealy, 1973) and fledge unaccompanied by their parents. At the other extreme, Synthliboramphus murrelets depart with their chicks two days after hatching ('precocial'; Sealy, 1973), and both parents provide care at sea. In the tribe Alcini, thick-billed murres (Uria lomvia), common murres, and razorbills (Alca torda) have a short period of biparental care at the breeding site (15-20 days) and partly grown 
chicks (15-30\% of adult body mass; 'intermediate'; Sealy, 1973) depart with the male parent to sea for an additional 3-4 weeks of exclusively paternal care (Gaston \& Jones, 1998). Partly grown dovekie chicks (Alle alle), the fourth Alcini member, also depart the colony with their male parent (27 days after hatching; Stempniewicz, 1995; Harding et al., 2004), but with 68-72\% of adult body mass ('semiprecocial', Sealy, 1973, Norderhaug, 1980; Stempniewicz, 2001; Harding et al., 2004).

The most common explanation for the evolution of departure to sea of the partly-grown chicks of the Alcini tribe is the constraint on provisioning at the colony imposed by the load-carrying capacity (Houston et al., 1996; Gaston \& Jones, 1998). These large auks have the highest wing loading of all seabirds (Greenwalt, 1962; Spear \& Ainley, 1997), which is a tradeoff for having excellent diving capacity. Consequently the flight costs of foraging and meal delivery are energetically expensive. However, this limitation should not apply so much to the much smaller planktivorous dovekies, and its applicability to razorbills that provision their chicks with multiple (sometime large) fish is questionable. Another explanation for early chick departure is that predation risk is high at the colony compared to at sea (Cody, 1971; Ydenberg, 1989; Ydenberg et al., 1995). Ydenberg's (1989) model for the intermediate-fledgling alcids assumed that chicks have a lower mortality rate at the colony than at sea, but grow faster at sea than at the colony. Neither of these two assumptions are rigorously testable and more importantly, this 'tradeoff' hypothesis has no exclusive predictions (Gaston \& Jones, 1998).

It is also important to keep in mind that males play the dominant role in raising chicks in many other species of Charadriiformes. For example, in socially monogamous scolopacids, females attend chicks for a shorter period after hatching than do males, and may even desert late in incubation (Gratto-Trevor, 1991; Piersma, 1996a; Payne \& Pierce, 2002). A similar but weaker trend also occurs in socially monogamous Charadriids (Piersma, 1996b). Therefore, a functional explanation for paternal care late in chick development specific to auks of the tribe Alcini may not be required. In this paper we take as a starting point only that 'intermediate' chick colony departure is a phylogenetically fixed characteristic of the auk tribe Alcini.

Despite the different stages of development at chick departure, modes of chick provisioning, and nest-site characteristics (murres: open nests; razor- 
bills: open and crevice nests; dovekies: crevice nests), the four Alcini members share a unique 'intermediate' form of parental care; biparental care at the breeding site and uni-male parental care at sea. Two interesting questions that arise from patterns of parental care among the auk species are: Why do males accompany chicks to sea?, and How do the sexes allocate parental effort at the breeding site before paternal care begins when the chick departs the colony?

Differences in energy expenditure due to different female-male constraints at the breeding site may cause one sex to be in better condition and thus better able to finish raising the chick at sea. For instance, different mortality rates (Nelson, 1978), population ratios (Tershy \& Croll, 2000), foraging strategies (Markman et al., 2004), and aggressive behaviour (Burger, 1981; Fraser et al., 2002) are some factors that appear to affect the division of parental roles and effort allocation between sexes in biparental care species. It has been suggested that the risk of loss of paternity can limit the allocation of male parental effort; so males should invest parentally in proportion to their probability of siring their mates' young (Trivers, 1972; Maynard Smith, 1977). Although both sexes guard their mates in an effort to assure paternity and to maintain pair bonds, extra-pair copulations and, to a lesser degree successful fertilizations occur in murres (thick-billed murres: Gaston \& Hipfner, 2000; common murres: review Ainley et al., 2002) and razorbills (Wagner, 1992). Before egg-laying (3-4 weeks), males are continuously present at the breeding site (common murres) and/or mating arenas (razorbills) while female visitation is occasional (Gaston \& Jones, 1998). By doing this, males seem to reduce their uncertainty of paternity and potentially increase the number of offspring they father (Gaston \& Jones, 1998). However, during this time males engage in fights and are likely to fast or have reduced opportunities to feed (Birkhead et al., 1985), so overall they should have higher risk and energy costs than females. Theoretical models predict conflicts of interest in the level of parental effort between sexes, so in some circumstances each parent's fitness can be enhanced at the expense of their partner's effort (Houston \& Davies, 1985; McNamara et al., 1999). On the other hand, individuals in species with long-term monogamy, such as the murres (review Gaston \& Hipfner, 2000; review Ainley et al., 2002) and razorbills (review Hipfner \& Chapdelaine, 2002), are expected to be less likely to exploit their partners because maintaining their partners' condition enhances the fitness of both parents (reviewed in Mock \& Fujioka, 1990; 
Fowler, 1995). Thus, individuals of species with long-term pair bonds may distribute parental effort such that the partner who will benefit the most from contributing less parental effort does less work (K.M. Jones et al., 2002). We hypothesize that a male's effort at the breeding site will be lower than a female's because of the male's initial energy expenditure guarding their mate prior to egg laying. On the other hand, female auks produce a relatively large egg, from which hatches a semi-precocial chick (Cramp, 1985). This initial parental investment, although costly, may influence the female's decision to compensate for their partner's reduced parental effort at the breeding site. As a result, males might be in better condition than females to finish raising the chick at sea.

Both murres and razorbills are central place foragers so they have to commute several times a day between their nests and foraging areas to feed their chicks. Foraging is energetically expensive for these flapping-flight and pursuit-diving species (Birt-Friesen et al., 1989; Obst \& Nagy, 1992; Bech et al., 2002; Jodice et al., 2003). Thus, foraging for chick provisioning must be more costly than incubation/brooding at the colony. Taking all these factors into consideration we predict that early in the chick-rearing period, males might allocate most of their time at the breeding site, and females would spend most of their time foraging for chick provisioning. Equal parental investment in breeding site defence before chick departure is expected for both species. After chick departure, males will provide all the care for several weeks but will not have the additional effort of flying for chick feeding as they raise the chick at their feeding grounds (Gaston \& Jones, 1998).

The aim of this study is to compare two sympatric Alcini species with similar chick-rearing behaviour, to determine intra and inter-specific patterns in parental behaviour between sexes. Thus, we examined four components of parental care: breeding site attendance (egg/chick care and breeding site defence), provisioning rates, prey size delivered to chicks, and foraging trips. This allowed us to quantify the contribution of both sexes to parental care at the breeding site of thick-billed murres and razorbills at the Gannet Islands, Labrador.

Understanding how males and females distribute parental roles may give us insights into how evolution has shaped forms of parental care, the extent to which morphological, physiological and behavioural factors limit the allocation of parental effort, and why the transition to paternal care at sea occurs in the first place. 


\section{Methods}

Behavioural observations were undertaken during the incubation and chickrearing periods (June-August) of thick-billed murres (2000-2001) and razorbills (2001-2002) at GC4, one of the six Gannet Islands located on the low arctic coast of Labrador, Canada $\left(53^{\circ} 56^{\prime} \mathrm{N}, 56^{\circ} 32^{\prime} \mathrm{W}\right)$.

We studied a total of 15 thick-billed murre pairs and 31 razorbill pairs. Both groups were located in the same cliff area ('Grey Cup') on the north side of the island with about 150 and 45 open breeding sites of murres and razorbills respectively. Behavioural observations were undertaken from a blind, using a zoom telescope $(20-60 \times, 60 \mathrm{~mm})$ and binoculars $(10 \times$, $50 \mathrm{~mm}$ ), between dawn to dusk (04:00-22:00 h; sunrise occurred between 03:30 $\mathrm{h}$ and 04:00 $\mathrm{h}$ and sunset between 21:30 $\mathrm{h}$ and 22:00 h). Two observers made daily observations in double shifts of $4.5 \mathrm{~h}$ each with an equivalent resting time in between shifts. Most birds were already incubating eggs when we started the observations. The period of observation covered most of incubation (9-27 days post-laying) for razorbills and half of incubation for thick-billed murres (7-15 days post-laying) except when egg loss occurred. Observations continued through hatching until chicks were fledged. Hence, observations covered most of the brooding period in both species (6-16 days for razorbills, and 5-15 days for murres), except in cases of breeding failure.

Individuals were identified by temporary marks of picric acid (yellow) or fluorescent paint (green, pink and orange) delivered from a small container ( $10 \mathrm{ml}$ of the marking liquid) attached to the tip of a $4 \mathrm{~m}$ graphite pole. This method allowed marking from above the birds without disturbing the colony. The birds' reaction to the marking liquid was similar to that produced by falling guano, which is a normal occurrence in the colony, so additional disturbance caused by marking was minimal. Identifying marks and life history information of individuals were recorded on cards for quick reference.

Breeding sites were scanned every 10 minutes and the presence or absence of marked birds was recorded so that the time spent at the breeding site per day could be calculated. When both adults were present, the 'off-duty' parent was observed interacting aggressively with conspecifics and predators (great black-backed gulls, Larus marinus), and also preening their mates (Paredes et al., unpublished data), so we assumed birds were mainly engaged in the defence of the breeding site, mate and offspring. The identity of the adult incubating or brooding ('egg/chick care') and that of the 'off-duty' parent 
('breeding site/mate defence') was recorded and the time spent in these activities calculated separately. The departure and arrival times of adults, and chick provisioning events, were recorded continuously to quantify chick provisioning frequencies and foraging trip durations. During chick provisioning, we identified prey items to the species level when possible, recorded the number of items per load, and estimated the length of prey items when possible. We used direct estimation of the prey items' length compared to the length of the gape as a reference unit for estimating prey size (e.g. two-times gape length). Then, we used the mean gape length of males and females to estimate the prey item length in centimeters. A similar method of prey length estimation was used by Gaston \& Nettleship (1981) but using the culmen as a reference unit.

One member of each pair was captured during the chick-rearing period for permanent marking and sex determination. Murres were captured with a noose of nylon monofilament (1.5 mm diameter) on the end of a 4-m graphite pole. Razorbills were captured with a small weighted noose-carpet attached to one end of $20 \mathrm{~m}$ of nylon monofilament line (1.5 mm diameter) and with the other end attached to $3-\mathrm{m}$ wooden pole. The noose end was positioned on cliff ledges used by the birds, so they were captured by the leg as they approached or departed their breeding site. Birds were marked with a field readable stainless steel leg band and a colour band. Blood samples $(0.5 \mathrm{ml})$ were taken from the tarsal vein and stored in $95 \%$ ethanol for sex determination using molecular DNA analysis (Fridolfsson \& Ellegren, 1999). The results of sexing were obtained after the season was finished (observers were blind to the sex of birds) and then matched with the ID cards to interpret behavioural data.

Every year, we followed a large number of thick-billed murres, (4950 pairs) and razorbills (36-41 pairs), including the birds used for behavioural observations and for breeding success determination. Pairs were followed from incubation to chick departure to determine overall breeding success (proportion of eggs that survived to chick departure per active breeding site), fledgling success (proportion of chicks that fledged per active breeding site), and the duration (days) of the brooding period.

\section{Data analysis}

Two years of behavioural data (breeding site attendance: egg/chick care and breeding site/mate defence, chick provisioning, and foraging trips) and 
chick diet (species and size) were pooled for each species for the analysis of parental care because no differences in breeding success and duration of chick-rearing were found between years (see below). For each individual, we quantified time spent at the breeding site per $24 \mathrm{~h}$. Even though the observation period only covered daylight hours (c. $18 \mathrm{~h}$ ), previous studies have shown that male and female thick-billed murres at the Gannet Islands do not make parental roll changes ('change-overs') at night (Jones et al., 2002). In this study, most of the same birds present at dusk were present the following morning with soiled plumage, suggesting they did not leave the breeding site during the night. In addition, we did not see flight activity of murres or razorbills at the colony during opportunistic observations in moonlight conditions during the night. Consequently, we added six hours (dark time) to individuals present at dusk and dawn at the breeding site. The initial sample size of murre $(N=15)$ and razorbill $(N=31)$ pairs used for the behavioural analysis of the incubation period decreased slightly during the brooding period because of breeding failure. We did not include data from new pairs, except for the analysis of prey species delivered to chicks between sexes to be able to find possible differences in second prey items. Only $1 / 15$ murre pairs and 5/31 razorbill pairs were followed during the two study years. Because of the small ratio of repeated pairs, we believe that possible data duplication, assuming birds behaved the same in both years, might have not affected the statistical analysis. However, we tested for possible effect of data duplication in razorbills by excluding one-year of data (randomly chosen) of replicated pairs and compared these results with those of complete data. Female razorbills spent longer time incubating $\left(12.90 \pm 0.30 \mathrm{~h} \mathrm{~d}^{-1}\right)$ than males $\left(11.10 \pm 0.30 \mathrm{~h} \mathrm{~d}^{-1}\right)$ when one-year data of repeated pairs was excluded (Paired $t$-test: $t_{1,25}=3.049, p=0.005$ ) and when it was not (see below). We did not use data from repeated individuals for independent statistical tests.

We calculated the number ( bation and brooding shifts for each species using the total number of days of observation per period. The time spent at the breeding site ('breeding site attendance') was sub-divided into time spent incubating or brooding the chick ('chick care'), and off-duty time. Breeding site and sub-categories of attendance were analysed separately for each sex and pair-wise per breeding site. The timing of breeding-site attendance by males and females was calculated using hourly checks for attendance of the egg or chick ( $24 \mathrm{~h}$ period) during 
the incubation and brooding period. Timing of chick provisioning was calculated based on the total number of feedings of males and females recorded during the brooding period.

Chick provisioning rates (loads individual ${ }^{-1} \mathrm{day}^{-1}$ ), total number of trips (number individual ${ }^{-1} \mathrm{day}^{-1}$ ), and duration of foraging trips ( $\mathrm{h}$ individual ${ }^{-1}$ day) were averaged per individual across three chick-age groups (one, two, and three weeks old). These data were analysed using two-way ANOVAs with sex and chick-age group as the main factors. In addition, paired comparisons were undertaken between sexes matched per breeding site to control for individual differences and confirm results from the cross-sectional analysis. Load sizes were also determined and compared between sexes in both species (as was number of prey items per load for razorbills). It was not possible to distinguish between bathing trips and feeding trips because birds could return to the breeding site with a fish after absences of less than 10 minutes. All foraging trips ('total') and those with meal delivery ('w/meal') were analysed separately so results could be related to parental care. The first foraging trip was usually performed by females, which normally spent the night at sea (Jones et al., 2002) and arrived at the breeding site in the early morning. Thus, in order to calculate the duration of the first foraging trip we assumed birds started to forage right after sunrise $(03: 30 \mathrm{~h})$. This assumption is supported by large number of murres and puffins observed on the water just before dawn at Witless Bay, Newfoundland (Schneider et al., 1990).

\section{Statistical analysis}

Statistical analysis was carried out using SPSS version 11.5. We used parametric tests (ANOVA, independent $t$-test, and paired $t$-test) to compare groups if the residuals met the assumptions for the general linear model, and transformed data when they did not. For instance, data of foraging trip duration was log-transformed before statistical analysis to reduce skewness and variance of the means. Chi-Square tests with Yates's correction were used to compare proportions. Means were expressed $\pm \mathrm{SE}$ of the mean. All comparisons were two-tailed, and differences were considered significant when $p<0.05$. 


\section{Results}

Breeding success and duration of chick-rearing period

The reproductive success of murres (2000: 0.55 fledglings breeding site ${ }^{-1}$ ), $N=49 ; 2001: 0.74$ fledglings breeding site ${ }^{-1}, N=50$ ); and razorbills (2001: 0.85 fledglings breeding site ${ }^{-1}, N=41 ; 2002$ : 0.72 fledglings breeding site ${ }^{-1}, N=36$ ) did not differ significantly between years (murres: independent $t$-test: $t_{97}=-1.99, p=0.05$; razorbills: independent $t$-test: $t_{75}=1.41, p=0.16$ ). Of the murre's eggs that hatched, a similar proportion survived to chick departure in both years (2000: 0.93 fledglings breeding site $^{-1}, N=29$; 2001: 0.97 fledglings breeding site ${ }^{-1}, N=38$; independent $t$-test: $\left.t_{65}=-0.83, p=0.41\right)$. Similarly razorbill's fledging success did not differ between years (2001: 0.97 fledglings breeding site ${ }^{-1}, N=36 ; 2002$ : 1.00 fledglings breeding site ${ }^{-1}, N=26$; independent $t$-test: $t_{60}=-0.85$, $p=0.40$ ). In 2000, murres lost more eggs than in 2001 for unknown reasons, which may explain the marginal $p$ value for the overall breeding success of that year.

The duration of the chick-rearing period for murres (2000: $19.88 \pm 0.48$ days, $N=17 ; 2001: 20.33 \pm 0.80$ days, $N=18$ ) and razorbills (2001: $18 \pm 0.8$ days, $N=19 ; 2002: 19 \pm 0.60$ days, $N=10$ ) did not differ significantly between years (murres: independent $t$-test: $t_{33}=-0.48, p=$ 0.63 ; razorbills: independent $t$-test: $t_{27}=0.84, p=0.41$ ). For these reasons, data from the two study years were pooled for the analysis of parental care in each species. For both murres $(N=13)$ and razorbills $(N=21)$, all birds that were seen departing with a chick were males as confirmed by DNA analysis (Fridolfsson \& Ellegren, 1999).

\section{Breeding site attendance}

Thick-billed murres

The mean number of change-overs per day during incubation was $3.24 \pm 0.07$ (range 2-7) with three change-overs on most days $(63 \%, N=164)$. Occasionally two (14\%) change-overs occurred per day, otherwise there were four $(12 \%)$ or more $(11 \%)$. The duration of incubation bouts varied from 0.67 to $22.33 \mathrm{~h}$. On average, the duration of the first, second and third incubation bouts were $2.73 \pm 0.17 \mathrm{~h}, 10.98 \pm 0.36 \mathrm{~h}$ and $8.25 \pm 0.30 \mathrm{~h}$, respectively. 

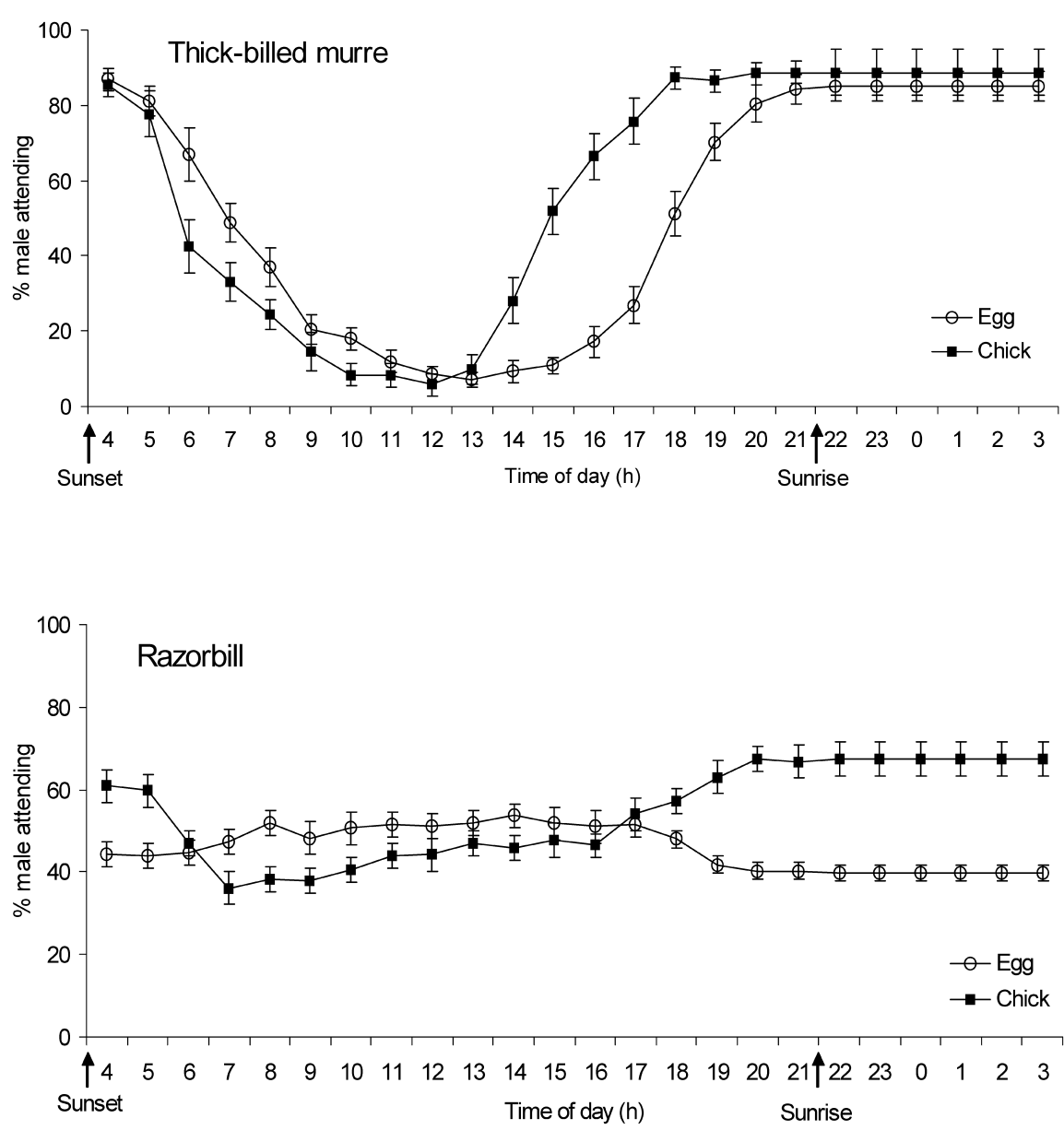

Figure 1. Timing of breeding site attendance of thick-billed murres and razorbills during the incubation ( $N=15$ pairs; $N=31$ pairs) and brooding ( $N=13$ pairs; $N=23$ pairs) period at Gannet Islands, Labrador. Means of males \pm SE are shown.

The first and third bouts were usually performed by males and the second by females.

Most males incubated eggs early in the morning (04:00-06:00 h) and late afternoon and night (19:00-03:00 h); while females incubated eggs mostly during the day and early afternoon (08:00-17:00 h; Figure 1). On average, males spent significantly more nights incubating eggs ( $8.9 \pm 1$ days, $N=15$; paired $t$-test: $\left.t_{12}=-6.775, p<0.001\right)$ than females $(1.3 \pm 0.36$ days, $N=15)$. During the incubation period, male murres $\left(14.66 \pm 0.51 \mathrm{~h} \mathrm{day}^{-} 1\right.$, 


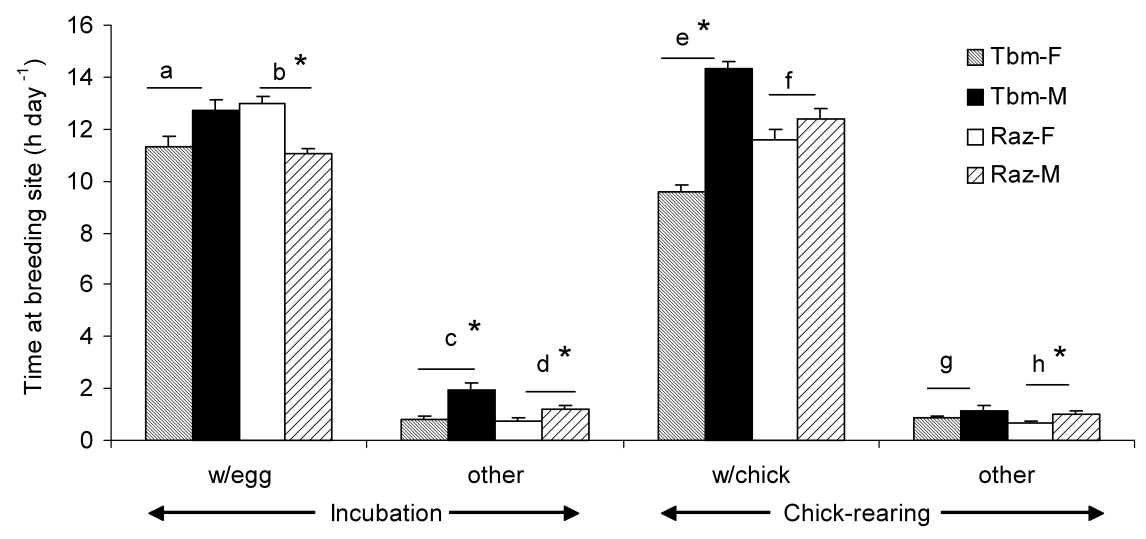

Figure 2. Time spent at the breeding site (Means \pm SE) by male $(M)$ and female $(F)$ razorbills (razo) and thick-billed murres (Tbm) at Gannet Islands, Labrador. The overall time spent at the breeding site has been broken in subcategories: incubating (w/egg), brooding (w/chick) and chick/mate defence and preening (other). Only the pair comparisons between sexes 'b', 'c', 'd', 'e', and 'h' were significant (*Paired $t$-test: $p<0.05$ ).

$N=15)$ spent significantly more time at the breeding site than their female mates $\left(12.14 \pm 0.32 \mathrm{~h}\right.$ day $-1, N=15$; paired $t$-test: $t_{14}=-3.15, p<$ 0.01 ). Even though the sexes did not differ in the daily amount of time allocated to incubate their eggs (paired $t$-test: $t_{14}=-1.75, p=0.10$ ), males devoted more time to certain other activities (e.g., breeding site defence and mate preening) at the breeding site than females (paired $t$-test: $t_{14}=-4.75$, $p<0.001$; Figure 2).

The mean number of change-overs per day during the brooding period was $5.34 \pm 0.2$ (range 3-12), with $40 \%$ of 101 days having five changeovers, $21 \%$ three, $13 \%$ seven, $9 \%$ four, and $7 \%$ six. The overall mean duration of brooding bouts was $4.49 \pm 0.18 \mathrm{~h}$ (range 0.17-17.17 h). The mean duration of the first, second, third, fourth and fifth chick-rearing bouts were $1.62 \pm 0.08 \mathrm{~h}, 5.73 \pm 0.36 \mathrm{~h}, 4.41 \pm 0.46 \mathrm{~h}, 4.12 \pm 0.41 \mathrm{~h}, 7.23 \pm 0.59 \mathrm{~h}$, respectively. The first and the last bout were usually performed by males. The timing of breeding site attendance of males and females during the brooding period was similar to that observed during the incubation period, except that females had earlier and shorter bouts (07:00-14:00 h; Figure 1). Males spent significantly more nights with the chick $(7.0 \pm 0.49$ days, $N=13)$ than females $\left(0.92 \pm 0.29\right.$ days, $N=13$; paired $t$-test: $t_{12}=-9.013, p<0.001$; Figure 1). 


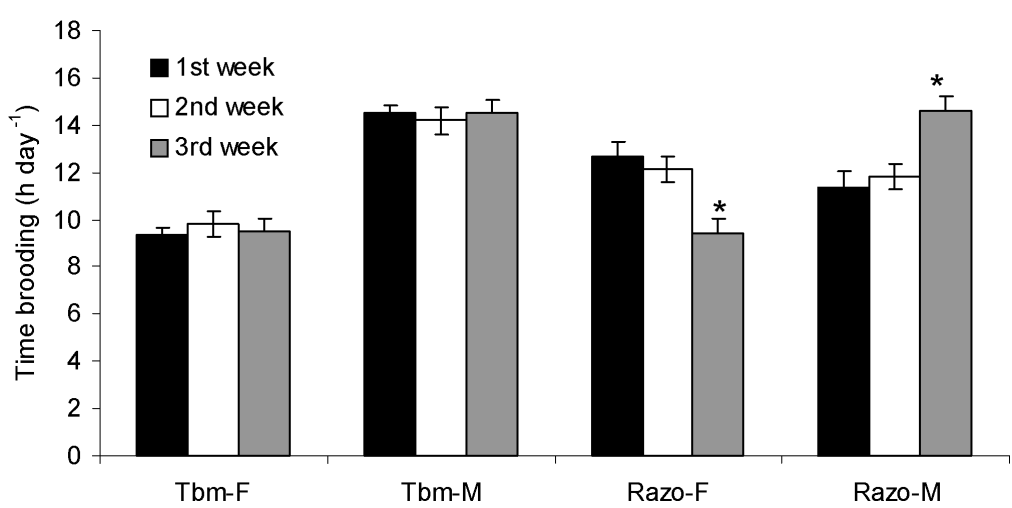

Figure 3. Sex differences on the brooding duration of thick-billed murres ( $N=13$ pairs $)$ and razorbills ( $N=21$ pairs) according to chick age categories. Data is shown as means \pm SE. Statistical differences within sexes were only for razorbills (*Turkey HSD: $p<0.01$ ).

During the brooding period, male murres $\left(15.52 \pm 0.30 \mathrm{~h} \mathrm{day}^{-1}, N=13\right)$ spent significantly more time attending the breeding site than their female mates $\left(10.44 \pm 0.30 \mathrm{~h} \mathrm{day}^{-1}, N=13\right.$; paired $t$-test: $\left.t_{13}=-9.1, p<0.001\right)$. Males spent significantly more time brooding their chicks than females did (paired $t$-test: $t_{13}=-8.7, p<0.001$ ); and the additional time that each parent spent at the breeding site (i.e., when their mates were present brooding) did not differ significantly between sexes (paired $t$-test: $t_{13}=-1.93$, $p=0.08$; Figure 2). The time spent brooding did not depend on chick age (females: ANOVA: $F_{2,42}=0.23, p=0.79$; males: ANOVA: $F_{2,42}=0.13$, $p=0.88$; Figure 3 ).

\section{Razorbills}

The mean number of incubation change-overs per day was $2.90 \pm 0.06$ (range 1-9). Most days razorbills had two $(48 \%, N=372)$ or three changeovers $(30 \%)$, but occasionally had four $(9 \%)$, five $(7 \%)$ or more $(4 \%)$. The overall mean duration of incubation bouts was $8.23 \pm 0.18 \mathrm{~h}$ (range 0.17 $24 \mathrm{~h}$ ). The mean duration of the first, second, third, fourth and fifth incubation bouts was $5.43 \pm 0.21 \mathrm{~h}, 12.20 \pm 0.32 \mathrm{~h}, 7.39 \pm 0.39 \mathrm{~h}, 6.45 \pm 0.62 \mathrm{~h}$, and $6.69 \pm 0.68 \mathrm{~h}$, respectively. Male and female razorbills were equally likely to be found at the breeding site during the day (04:00-18:00 h; Figure 1). However, on average females spent significantly more nights incubating the egg (11.6 \pm 1.17 days) than males (7.6 \pm 0.74 days; paired $t$-test: $t_{19}=3.21$, $p=0.005)$. 
Overall, female razorbills $\left(13.69 \pm 0.29 \mathrm{~h} \mathrm{day}^{-1}, N=31\right)$ spent significantly more time at the breeding site than males during incubation $\left(12.23 \pm 0.22 \mathrm{~h} \mathrm{day}^{-1}\right.$; paired $t$-test: $\left.t_{30}=3.02, p<0.01\right)$. These differences were mainly due to the greater amount of time females spent incubating the eggs than their mates (paired $t$-test: $t_{30}=3.75, p<0.01$; Figure 2). Males spent significantly more time than females in other activities at the breeding site, such as breeding site defence, (paired $t$-test: $t_{30}=-3.64$, $p<0.01$; Figure 2).

During the brooding period razorbills had on average $6.06 \pm 0.15$ (range: $2-15)$ change-overs in 24 hours, with most days (64\%, $N=219)$ having four to seven change-overs. The overall mean duration of brooding bouts was $3.95 \pm 0.11 \mathrm{~h}$ (range 0.17-19 h). On average the first, second, third, fourth, fifth, sixth and seventh brooding bouts lasted $2.56 \pm 0.10 \mathrm{~h}, 4.90 \pm 0.21 \mathrm{~h}$, $3.28 \pm 0.22 \mathrm{~h}, 4.00 \pm 0.29 \mathrm{~h}, 4.00 \pm 0.36 \mathrm{~h}, 3.45 \pm 0.36 \mathrm{~h}$ and $4.40 \pm 0.49 \mathrm{~h}$, respectively.

Females were at the breeding site more often between 07:00 and 10:00 $\mathrm{h}$ and males between 17:00 and 05:00 $\mathrm{h}$ (Figure 1). In contrast to the incubation period, males spent significantly more nights with the chick $(6.65 \pm 0.5$ days) than females $\left(3.75 \pm 0.61\right.$ days, paired $t$-test: $t_{19}=-3.28, p=$ $0.004)$. Overall, razorbill males $\left(13.41 \pm 0.42 \mathrm{~h} \mathrm{day}^{-1}, N=23\right)$ and females $\left(12.28 \pm 0.42 \mathrm{~h} \mathrm{day}^{-1}, N=23\right)$ did not differ in the time spent at the breeding site (paired $t$-test: $t_{21}=-1.44, p=0.17$ ) during chick rearing. However, time spent brooding differed according to chick age for males (ANOVA: $F_{2,57}=7.67, p=0.001$ ) and females (ANOVA: $F_{2,57}=7.66, p=$ 0.001 ; Figure 3 ). Females brooded one to two weeks old chicks significantly more than three-week old chicks (Turkey HSD: $p<0.01$ ), whereas males spent significantly more time brooding three-week old chicks (Turkey HSD: $p<0.01$ ). Overall, males spent significantly more time at the breeding site engaged in other activities (e.g., breeding site or mate defence) when their partners were brooding than females did (paired $t$-test: $t_{21}=-2.91$, $p<0.01$; Figure 2).

\section{Chick-provisioning}

\section{Thick-billed murres}

Females had a bimodal timing of chick feeding; $41 \%$ ( $N=290$ feedings) of the total feedings occurred early in the morning (04:00-09:00 h), and 51\% 

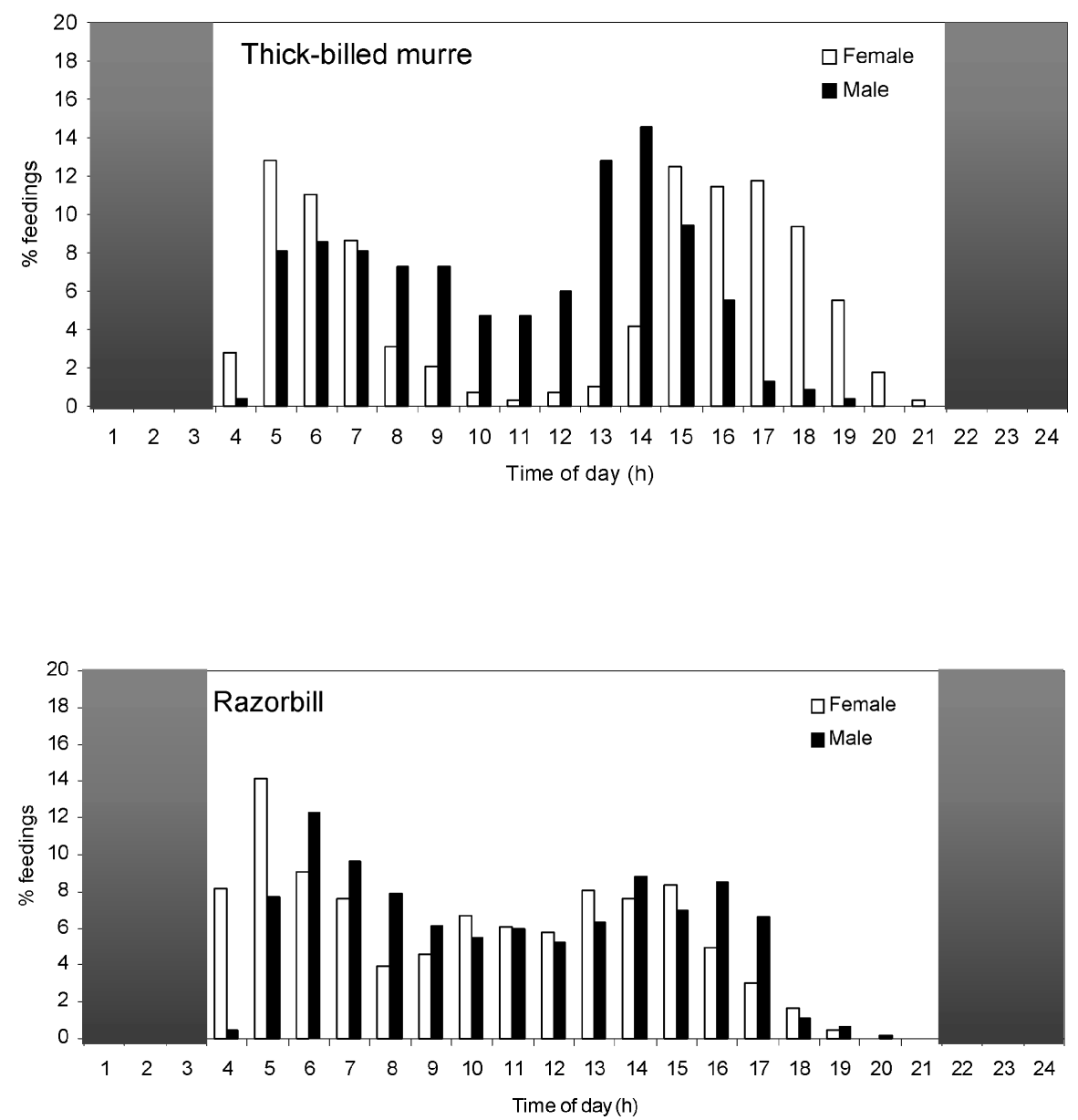

Figure 4. Timing of chick provisioning of thick-billed murres and razorbills at Gannet Islands, Labrador. Proportions of the total number of feedings of males (murres: $N=235$; razorbills: $N=456$ ) and females (murres: $N=290$; razorbills: $N=660$ ) are shown.

late in the afternoon (14:00-19:00 h; Figure 4). In contrast, males had a single and long period of chick feeding; $97 \%$ ( $N=235$ feedings) of the total feedings occurred between 05:00-19:00 h. However, 42\% of the feedings occurred after midday between 13:00-16:00 h (Figure 4).

Chick provisioning frequency differed significantly between sexes (females: $2.84 \pm 0.18$ loads day ${ }^{-1}, N=13$; males: $2.26 \pm 0.12$ loads day $^{-1}$, $N=13$; two-way ANOVA: $F_{1,72}=7.78, p<0.01$ ); but provisioning frequency did not vary with chick age (one week, $2.25 \pm 0.19$ loads day ${ }^{-1}$; 
two week, $2.76 \pm 0.18$ loads day $^{-1}$; three week, $2.63 \pm 0.21$ loads day $^{-1}$; $\left.F_{2,72}=2.20, p=0.12\right)$. The interaction term sex*chick age was not significant $\left(F_{2,72}=2.48, p=0.06\right)$. Further analysis of the main factors showed that only the provisioning rates of females differed significantly among chick-age groups (females: ANOVA: $F_{2,39}=4.09, p=0.03$; males: ANOVA: $\left.F_{2,39}=0.08, p=0.93\right)$. Female murres fed their chicks significantly more often than males during the second (ANOVA: $F_{1,24}=11.01$, $p<0.01$ ) and third weeks after hatching (ANOVA: $F_{1,24}=4.94, p=0.04$ ), but did not differ in feeding rates when chicks were less than one week old (ANOVA: $F_{1,24}=0.12, p=0.73$; Figure 5 ). The total chick provisioning per pair did not vary among chick-age groups (ANOVA: $F_{2,36}=0.28, p=0.09$; Figure 5). Thick-billed murres always delivered a single prey item per load. The length of prey items was calculated based on the estimation of the gape, which was significantly larger for males $(6.11 \pm 0.05 \mathrm{~cm}, N=38)$ than for females $\left(5.90 \pm 0.04 \mathrm{~cm}, N=43\right.$; independent $t$-test: $t_{79}=-3.29$, $p<0.01)$. The length of prey items delivered did not vary between males and females (female: $12.8 \pm 0.33 \mathrm{~cm}, N=13$, male: $13.4 \pm 0.16 \mathrm{~cm}$, $N=13$; two-way ANOVA: $F_{1,72}=2.74, p=0.10$ ) or chick-age group (one week: $12.8 \pm 0.28 \mathrm{~cm}, N=26$; two week: $13.4 \pm 0.40 \mathrm{~cm}, N=26$; $\left.13.1 \pm 0.26 \mathrm{~cm}, N=26 ; F_{2,72}=0.94, p=0.40\right)$. There was no interactive effect of the main factors on the length of the prey delivered $\left(F_{2,72}=0.36\right.$, $p=0.70)$.

\section{Razorbills}

Females and males fed their chicks throughout the day (04:00-20:00 h, Figure 4). Both sexes had two small peaks of prey delivery early in the morning (females: 04:00-07:00 $\mathrm{h}=39 \%, N=660$ feedings; males: 05:00-08:00 $\mathrm{h}=$ $38 \%, N=456$ feedings), and early in the afternoon (females: 14:00-16:00 h =24\%; males: 15:00-17:00 $\mathrm{h}=24 \%$; Figure 4).

Razorbills delivered an average of $2.13 \pm 0.08$ items (range 1-8) per load. On average the number of prey items per load did not differ significantly between females ( $2.20 \pm 0.11$ preys load $\left.^{-1}, N=14\right)$ and males $(2.06 \pm 0.11$ preys load ${ }^{-1}, N=14$; two-way ANOVA: $F_{1,78}=0.75, p=0.34$ ); or with chick age (one week: $2.01 \pm 0.11$ preys load ${ }^{-1}, N=28$; two week: $2.25 \pm 0.13$ preys load ${ }^{-1}, N=28$; three week: $2.12 \pm 0.15$ preys load $^{-1}$, $\left.N=28 ; F_{2,78}=0.79, p=0.46\right)$. There was no interactive effect of the 

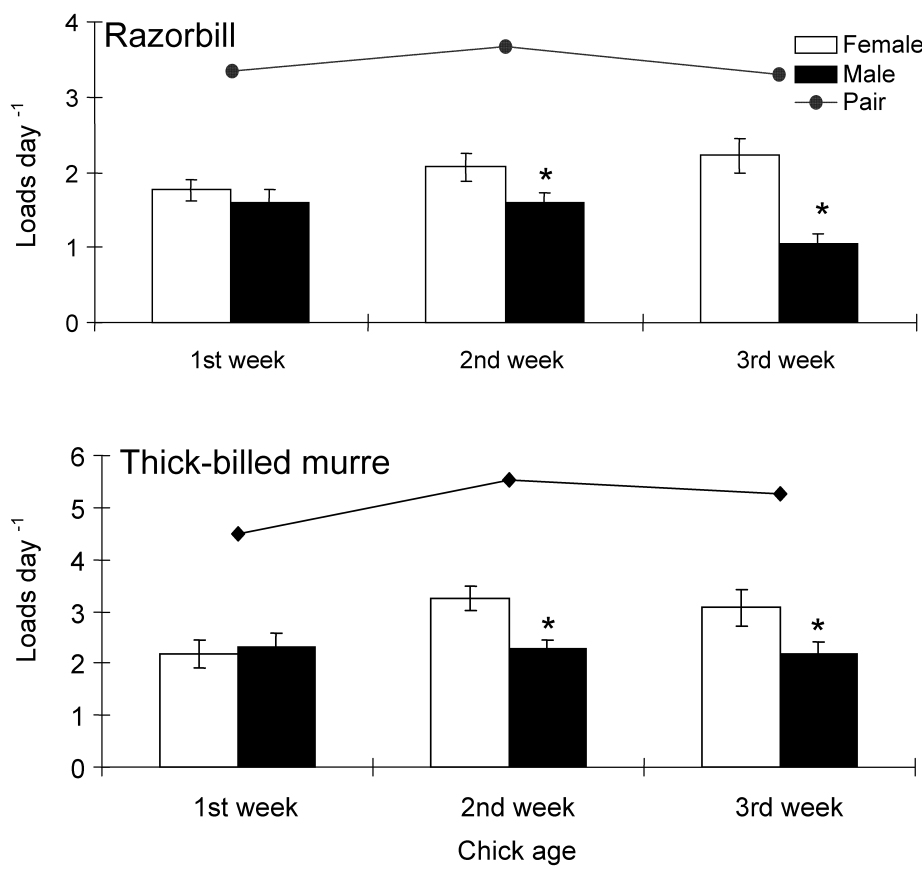

Figure 5. Provisioning rates (Means \pm SE) of male and female razorbills ( $N=19$ pairs) and thick-billed murres $(N=13)$ according to chick age categories at Gannet Islands, Labrador. Statistical differences between sexes in each category are shown (*ANOVAs, $p<$ 0.05). No significant differences of the total chick provisioning were found among chick age categories in both species (ANOVAs, NS).

main factors on the number of prey items delivered per load $\left(F_{2,78}=0.46\right.$, $p=0.63)$.

Based on these results, we used the number of loads provided per day to analyse differences in provisioning rates between males and females.

The provisioning rate of razorbills differed significantly between the sexes (females: $2.02 \pm 0.11$ loads day ${ }^{-1}, N=19$; males: $1.42 \pm 0.09$ loads day $^{-1}$, $N=19$; two-way ANOVA: $F_{1,108}=18.94, p<0.001$ ), but not with chick age (one week: $1.67 \pm 0.12$ loads day ${ }^{-1}$; two week: $1.83 \pm 0.12$ loads day $^{-1}$; three week: $1.65 \pm 0.16$ loads day $\left.{ }^{-1} ; F_{2,108}=0.72, p=0.491\right)$. However, the interaction term sex $*$ chick age was significant $\left(F_{2,108}=4.48\right.$, $p<0.02)$. Further analysis of the main factors showed that sexes did not differ on the feeding rates when chicks were less than one week old (ANOVA: $F_{1,36}=0.49, p=0.49$; Figure 5), but the feeding rates of females were significantly higher than those of males when chicks were two (ANOVA: 
$F_{1,36}=4.50, p=0.04$ ) and three weeks old (ANOVA: $F_{1,36}=20.47$, $p<0.001$; Figure 5). Provisioning rates of males differed among chick-age groups (ANOVA: $F_{2,54}=4.04, p=0.02$ ), with males feeding one-week old chicks significantly more frequently than older chicks (Tukey HSD: $p=$ 0.04). Provisioning rates of females did not vary with chick age (ANOVA: $F_{2,54}=1.65, p=0.20$; Figure 5). The combined chick provisioning per pair did not vary with chick age (ANOVA: $F_{2,54}=1.02, p=0.37$; Figure 5).

The length of prey items was calculated as a proportion of the gape length of males and females. The gape length was significantly larger in males $(5.42 \pm 0.04 \mathrm{~cm}, N=28)$ than in females $(5.25 \pm 0.05 \mathrm{~cm}, N=34$; independent $t$-test: $\left.t_{60}=-2.59, p=0.01\right)$. We inferred that females delivered prey items that varied between 2.63 and $15.75 \mathrm{~cm} \mathrm{long}$, and males delivered prey items between 4.07 and $16.26 \mathrm{~cm}$ long. We used the mean length of multiple-prey loads for the comparison between sexes because no significant differences were found in the number of prey items per load (see above). The mean length of prey items did not differ between females $(9.82 \pm 0.17 \mathrm{~cm}, N=14)$ and males $(10.19 \pm 0.21 \mathrm{~cm}, N=14$; two-way ANOVA: $F_{1,78}=1.69, p=0.20$ ) or among chick-age groups (one week: $9.90 \pm 0.29 \mathrm{~cm}, N=28$; two week: $9.82 \pm 0.17 \mathrm{~cm}, N=28$; three week: $\left.10.06 \pm 0.24 \mathrm{~cm}, N=28 ; F_{2,78}=0.13, p=0.88\right)$. There was no interaction of the main factors on the mean length of prey items $\left(F_{2,78}=0.078\right.$, $p=0.93)$.

\section{Foraging trip frequency and duration}

Thick-billed murres

During the chick-rearing period, murres performed a mean of $3.72 \pm 0.12$ foraging trips per day (range 1-8) that lasted an average of $1.90 \pm 0.11 \mathrm{~h}$ (range $0.17-12 \mathrm{~h}$ ). Foraging trips with food delivery to the chick occurred after absences from the breeding site of 10 or more minutes. Overall, females performed significantly more foraging trips per day than males did (two-way ANOVA: $F_{1,72}=7.21, p<0.01$, Table 1$)$. The number of foraging trips did not depend on chick age (one week: $3.40 \pm 0.20$ trips day $^{-1}, N=26$, two week: $3.90 \pm 0.20$ trips day ${ }^{-1}, N=26$, three week: $3.85 \pm 0.20$ trips day $^{-1}$, $\left.N=26 ; F_{2,72}=1.90, p=0.16\right)$ and no interactive effect of the main factors was detected $\left(F_{2,72}=0.81, p=0.45\right)$. Similar results were found when individual differences were controlled using a paired comparison of 
Table 1. Foraging trips of female and male thick-billed murres (13 pairs) and razorbills (21 pairs) at Gannet Islands, Labrador

\begin{tabular}{lccccc}
\hline & \multicolumn{2}{c}{ Thick-billed murre } & & \multicolumn{2}{c}{ Razorbill } \\
\cline { 2 - 3 } \cline { 5 - 6 } & Female & Male & & Female & Male \\
\hline Number of trips per day & $4.02 \pm 0.2^{*}$ & $3.40 \pm 0.2$ & & $3.09 \pm 0.1$ & $3.32 \pm 0.1$ \\
Number of trips with meal delivery & $2.84 \pm 0.2^{*}$ & $2.26 \pm 0.1$ & & $2.02 \pm 0.1^{*}$ & $1.42 \pm 0.1$ \\
Trip duration $^{1}(\mathrm{hr})$ & $1.19 \pm 0.2$ & $2.40 \pm 0.2^{*}$ & & $1.93 \pm 0.2$ & $2.03 \pm 0.15$ \\
Trip duration with meal delivery $^{1}(\mathrm{hr})$ & $1.23 \pm 0.4$ & $3.04 \pm 0.3^{*}$ & & $2.50 \pm 0.4$ & $3.30 \pm 0.2^{*}$ \\
\hline
\end{tabular}

Means are given \pm SE. Significant differences between sexes are shown (*ANOVAs, $p<$ $0.01)$.

${ }^{1}$ Data were log-transformed before the statistical analysis.

the foraging trip frequency per breeding site between sexes (paired $t$-test: $t_{12}=2.89, p=0.01$ ).

The duration of foraging trips of males was significantly longer than that of females (log-transformed data, two-way ANOVA: $F_{1,72}=85.39, p<$ 0.001 , Table 1$)$. Foraging trip duration did not vary with chick age $\left(F_{2,72}=\right.$ $2.321, p=0.11)$ and the interaction term sex*chick-age group was not significant $\left(F_{1,72}=0.94, p=0.40\right)$. Similar results were found between sexes when their foraging trip durations were matched per breeding site (paired $t$-test: $t_{12}=-6.39, p<0.001$ ). The mean duration of foraging trips that ended in chick provisioning was significantly longer for males than for females (log-transformed data: ANOVA: $F_{1,24}=47.95, p<0.001$, Table 1 ). Foraging trips without chick provisioning did not differ significantly between sexes (female: $1.28 \pm 0.10 \mathrm{~h}$; male: $1.42 \pm 0.21 \mathrm{~h}$; ANOVA: $F_{1,24}=0.39$, $p=0.54)$.

Razorbills

During brooding, a mean of $3.21 \pm 0.09$ (range 1-14) foraging trips was performed per day, lasting on average $2.18 \pm 0.09 \mathrm{~h}$ (range 0.17-11.83 h). Foraging trips with food delivery occurred after absences from the breeding site of 10 or more minutes. The total number of foraging trips per day did not differ between sexes (two-way ANOVA: $F_{1,120}=1.76, p=0.19$, Table 1 ), nor with chick age (one week: $3.08 \pm 0.14$ trips day $^{-1}$; two week: $3.15 \pm$ 0.17 trips day $^{-1}$ three week: $3.38 \pm 0.16$ trips day $^{-1} ; N=42 ; F_{2,120}=$ $1.04, p=0.35)$. There was no interactive effect of the main factors on the 
number of foraging trips $\left(F_{2,120}=1.88, p=0.16\right)$. Similar results were found between sexes when their mean number of trips was matched per breeding site (paired $t$-test: $t_{20}=-1.04, p=0.31$ ). However, females had significantly more foraging trips with food delivery (see chick provisioning) than males (Table 1).

Foraging trip duration did not differ between the sexes (log-transformed data: two-way ANOvA: $F_{1,120}=0.400, p=0.53$, Table 1) or with chick age (one week: $2.03 \pm 0.24 \mathrm{~h}$; two week: $2.06 \pm 0.22 \mathrm{~h}$; three week: $\left.1.85 \pm 0.27 \mathrm{~h} ; F_{2,120}=0.71, p=0.49\right)$. No interactive effect of the main factors on trip duration was detected $\left(F_{2,120}=0.63, p=0.54\right)$. Similar results between sexes were found after matching the mean duration of trips per breeding site (paired $t$-test: $t_{20}=-1.38, p=0.18$ ). In contrast, the duration of foraging trips with food delivery was significantly longer for males than for females (ANOVA: $F_{1,42}=10.15, p<0.01$, Table 1 ). The mean duration of trips without food delivery did not differ between sexes (female: $1.42 \pm 0.18 \mathrm{~h}$; male: $1.10 \pm 0.15 \mathrm{~h}$, ANOVA: $\left.F_{1,42}=0.02, p=0.88\right)$.

\section{Discussion}

We studied two sympatric Alcini species, thick-billed murres and razorbills that have biparental care at the breeding site followed by exclusively paternal care at sea (Gaston \& Jones, 1998). Our objective was to determine inter and intra-specific patterns of parental roles between sexes to be able to understand why the male accompanies the chick to sea. Although a widespread tendency for paternal care late in chick rearing exists in Charadriiform birds (Gratto-Trevor, 1991; Piersma, 1996a, b; Payne \& Pierce, 2002), it is relatively rare among the alcids ( 4 of 23 extant species). Thus, our approach was to identify characteristics of two alcid species that could favour such a pattern.

\section{Intra-specific patterns}

We found different patterns in the time devoted to incubation by males and females between species. Both parents spent a similar amount of time incubating eggs in thick-billed murres, but female razorbills had longer incubating bouts than males. Common murres at the Gannet Islands behave similarly to thick-billed murres, that is females and males do not differ in the duration 
of incubation bouts (Verspoor et al., 1987). Likewise, female razorbills in the Gulf of the St. Lawrence, Quebec (Bédard, 1969) behave similarly to those at the Gannet Islands. Differences in levels of male effort during mate guarding prior to egg-laying may explain the different incubation patterns between species. Razorbills have more occurrences of extra-pair copulations than murres (Wagner, 1992; Hipfner \& Chapdelaine, 2002) and they need to commute between two locations, mating arenas and breeding sites, for mate guarding. Thus, male razorbills may start the incubation period in poorer condition than male murres and, for this reason, may be more selective in their parental duties and effort allocation. For example, if males are better than females in defending the nest, it would be of benefit to both parents for the male to spend more time and effort defending the nest than incubating (see intra-specific patterns below).

Thick-billed murres showed a consistent pattern in the timing of breeding site attendance during the incubation and brooding period. Most males incubated eggs or brooded chicks during early morning, late afternoon and, usually, over night. In contrast, females incubated eggs or brooded chick mostly during the middle of the day. Likewise, females had a bimodal period of chick feeding; $41 \%$ and $51 \%$ of their feedings occurred early in the morning and late in the afternoon respectively. Males had a single and long period of chick feeding during the day; however about half of their feeding occurred between 13:00-16:00 $\mathrm{h}$. These results support a previous chick-rearing study of murres, which used radio-transmitters and temperature loggers at Gannet Is. That study found that males foraged during the day and females foraged mostly before sunset and after sunrise (Jones et al., 2002). Conversely, but consistent with these results, another study reported that female common murres at Gannet Is.; incubated eggs during the day whereas males did so during the night (Verspoor, 1987). In contrast, we found that razorbills do not show sex differences in the timing of breeding site attendance and chick feeding. Males and females were found incubating or brooding at similar times of the day, as was found in a previous study of razorbills at the Isle of May $\left(56^{\circ} \mathrm{N}\right.$; Wanless \& Harris, 1986). Likewise, both sexes fed their chicks all through the day; and showed two small peaks of prey delivery early in the morning and early in the afternoon. During reproduction, thick-billed murres and razorbills are central place foragers, so traveling and searching effort can affect chick-provisioning (Orians \& Person, 1979) and therefore reproductive performance (Clode, 1993). Because murres are single loaders and 
deep-pursuit divers (Gaston \& Jones, 1998), the division of foraging time between sexes initiated during the incubation period may help to maximize their foraging effort during chick-rearing. In fact, several studies have shown the ability of murres to memorize and locate 'hot spots' of food during reproduction (Cairns \& Schneider, 1990; Davoren et al., 2003), and their strong fidelity to foraging areas at spatial scales of 1-20 km (Mehlum et al., 2001). On the other hand, razorbills are multiple prey loaders and shallow divers (see review by Hipfner \& Chapdelaine, 2002), suggesting that they might use different tactics than murres to reduce their foraging effort at sea. According to central place foraging theory, multiple prey loaders are expected to forage closer to the colony to reduce traveling time; if this is the case for razorbills require further investigation. In addition, the time spent searching within food patches is likely to be less for razorbills than for murres, as razorbills performed shorter dives to capture their prey higher in the water column or in shallow water (review by Hipfner \& Chapedelaine, 2002). Thus, razorbill's searching effort may not be as constrained as that of murres, and a strict division of foraging times between males and females may not be mandatory.

\section{Inter-specific patterns}

We hypothesized that sex-specific differences of murres and razorbills in energy expenditure at the time of departure may explain why males accompany chicks to sea. We expected parental care at the breeding site of both species to be mostly female-biased due to the male's initial expenditure of effort on mate guarding prior to egg-laying. We further expected that this would lead to males being in better condition than females at the time of departure to finish raising the chick at sea.

Incubating and brooding both seem to be energetically less expensive than chick provisioning in thick-billed murres (Gaston, 1985) and probably in razorbills. Foraging at sea for chick provisioning is the most time- and energyconsuming activity for seabirds (e.g., Chappell et al., 1993), especially for flapping-flight and pursuit-diving species (Birt-Friesen et al., 1989; Obst \& Nagy, 1992; Bech et al., 2002; Jodice et al., 2003), such as the large auks (Gaston \& Jones, 1998). In fact, thick-billed murres rearing chicks reduced their feeding rates and body mass, and have longer foraging trips when handicapped with data loggers (Paredes et al., 2005). As we predicted, we found 
that in both auk species males spent more time with chicks and provided fewer meals per day than females, although these results depended somewhat on chick age. Razorbill males spent more time with chicks greater than two weeks old, while murre's allocation of care did not differ among chick age groups (1-3 weeks). Nevertheless, males of both auk species spent more nights with chicks during the brooding period than females. In both species, males reduced their provisioning rates when chicks were more than a week old. We did not find differences in the prey sizes delivered by males and females in either species. Higher female contribution toward chick provisioning has been reported in common murres at Isle of May (Wanless \& Harris, 1986) and at Witless bay, NL (Wilhelm, 2004). However, no extra-male allocation toward brooding has been reported in common murres (Wanless \& Harris, 1986; Verspoor, 1987; Wilhelm, 2004). In razorbills, approximately equal parental contribution to night nest attendance and chick feeding has been reported at Skomer Is. (Wagner, 1992). These differing results may be explained by methodological differences; slight sex differences in parental behaviour might be less likely to detect when using sub-sample observations (other studies) instead of continuous daylight sampling (this study). Different foraging strategies within and between species may also affect parental behaviour in other localities (see intra-specific patterns). In dovekies, differences in nest attendance and chick provisioning only occur during the late chick-rearing period; females depart the colony and males provide all the care until chick departure (Harding et al., 2004). Assuming breeding site visitation was a reliable method to assess feeding rates in crevice nesters that feed regurgitated food (see Granadeiro et al., 1999), these different results may be explained by breeding biology. Because Dovekie chicks depart with the male when almost full grown (67-82\% of adult body mass), the time and effort males need to allocate at sea is likely to be less than for murres and razorbills (chicks $15-30 \%$ of adult body mass). In addition, flying in smaller dovekies may involve less effort than in larger auks. Thus, increased provisioning by the male at the end of the chick-rearing period may not be an energy constraint during reproduction.

By analyzing only foraging trips with meal delivery, we found that males of both species performed longer trips while females performed shorter, but more frequent trips, than males. These results suggest different foraging strategies between males and females, such as traveling to different foraging areas and/or diving at different levels of the water column when searching for 
food. In thick-billed murres, sexes do not differ in their dive duration or depth when capturing prey for chick provisioning (Paredes, in prep.). However, the return trips of males after the last dive and before chick feeding were longer in duration than those of females (Paredes, unpubl. data). Murres are likely to fly directly back to the colony from their foraging areas because they deliver a single fresh fish to their chicks (Benvenutti et al., 1998). Thus, if males travel farther to forage their flying costs for chick provisioning are likely to be higher than those of females. No data is available for razorbill diving behaviour between sexes so we are unable to determine whether the longer foraging trip durations of male razorbills were due to different foraging areas, diving effort or both. Nevertheless, the longer foraging trips of males are probably as energetically costly as the more frequent trips of females with meal delivery. Thus, the overall effort for chick provisioning is not likely female-biased as we predicted.

In relation to the role of breeding site defence, we found another interesting pattern in the time and activities of male and female parents at the breeding site when their mates were incubating or brooding. According to Birkhead $(1978 ; 1985)$, the off-duty parent generally defends the breeding site, while the on-duty parent avoids such aggressive interactions. We found that in both species males spent more time interacting aggressively with neighbours or intruders and preening their mates than females during incubation and brooding. These results are more suggestive of a male-biased role toward the defence of the breeding site, guarding of the mate and protection of the offspring. The extra time males spent at the breeding site may be important to reinforce long-term bonds and to ensure breeding site ownership, as males will leave earlier than females. Thus, male allocation of risk and effort toward the defence of the breeding site, egg or chick, and mate seems to be higher than that of females before chick and male departure to sea, which also contradict our prediction of equivalent parental care between sexes before chick and male departure.

In summary, we found males and females had different parental roles, but the level of parental effort at the breeding site does not seem to be femalebiased as we hypothesized. In fact, the opposite seems to be true, males spent more time brooding and defending the nest than females, while the total allocation in chick feeding seems to be sex balanced. After the initial effort of males and females in mate guarding and egg production, respectively, they seem to be able to recover their energy expenditure while engaged in their 


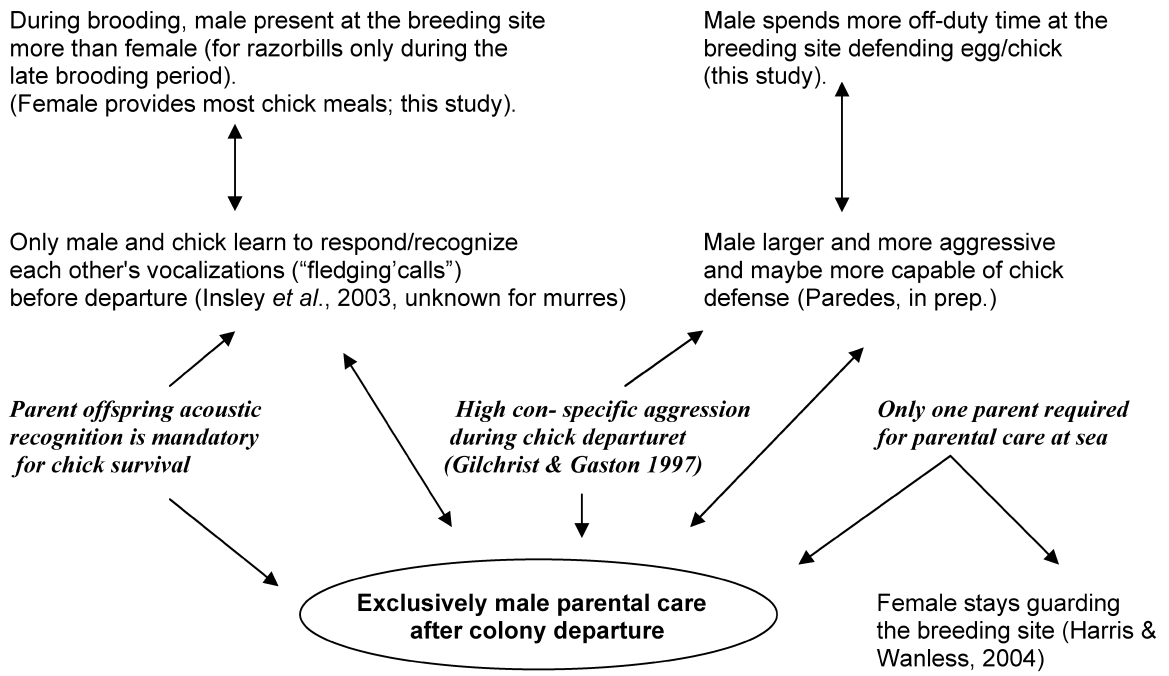

Figure 6. Patterns of parental roles of female and male thick-billed murre and razorbill at Gannet Is., and proposed explanation of male only care at sea.

parental roles during incubation. During this time, foraging is less costly and entirely focused on self-feeding. Flying and diving effort appears to be lower than during brooding because commuting between feeding areas and breeding sites is less frequent (this study), and they feed on prey located in shallower water (Benvenuti et al., 2002). Later on, males and females might be in reasonable shape to start taking care of the chick at the breeding site. Although we were unable to measure energy expenditure, our indirect measurements of parental effort (time and frequency of events) suggest an equal if not a male-biased parental effort at the breeding site. Thus, differences between males and females in energy expenditure do not explain the male's parental role at sea, as their condition is likely to be equal or lower than that of females at the time of departure. Instead, we believe that the most likely explanation for the patterns of parental roles found between sexes was the result of a chain of events favouring male involvement in chick brooding and care at sea (Figure 6).

A longer time spent brooding the chick by males may also benefit the development of parent-offspring acoustic recognition, which is crucial for chick survival at breeding site departure. Lefevre et al., (1998) reported that in thick-billed murres chick and parents were able to recognize each other's calls when the chick was three days old. They also reported that parents 
recognize their chicks' calls at fledging age, when chicks produced a unique 'fledging' call. Unfortunately, the sex of the birds in this study was not known. However the sample might have been male-biased, as suggested by the time of the day the recordings were made. We observed one incident in which a female murre did not respond to its chick's 'fledging' calls (c. $1 \mathrm{~m}$ apart) when it was left alone by the male during colony departure. The calling chick was pecked several times by other adults, without reaction from the female, which stayed at the breeding site, and eventually departed alone. Whether or not there is a sex-biased parent-offspring vocal recognition in thick-billed murres requires further investigation.

In razorbills, the onset of vocal recognition occurs during the last week before departure (Ingold, 1973; Insley et al., 2003), and it is only the male that appears to recognize its chick's calls, or at least responds to them (Insley et al., 2003). Other studies of alcids with different modes of development (Sealy, 1973) suggest that onset of recognition occurs when spatial cues are not sufficient to prevent misidentification (Harris, 1983; Jones et al., 1987). Murre breeding sites are less discrete and denser than those of razorbills, so the risk of chicks intermingling is higher. Thus, in comparison to razorbills parent-offspring mutual recognition by male and female murres is needed at an early stage. Later on, a longer investment of time at the breeding site by males of both species may be required to learn their chicks 'fledging's' calls and ensure parent-offspring recognition at departure. Like murres and razorbills, dovekies males also spent more time at the nest site than females during late chick-rearing period (Harding et al., 2004), which suggest malebiased time brooding may also function as a way to ensure parent-offspring vocal recognition at departure.

One of the main causes of murre chick mortality at departure is the aggressive interaction from neighbours at the colony and co-specifics at sea (Gilchrist \& Gaston, 1997). Our findings of a male-biased role towards the defence of egg and chick at the breeding site suggest sex differences in aggressive behaviour (see also Fraser et al., 2002). A larger and more aggressive sex may be more successful in protecting the chick during and after departure. All members of the Alcini tribe are slightly dimorphic species, with males being larger in mass and in most morphological dimensions (Gaston \& Hipfner, 2000; Wagner, 1999; Gaston \& Jones, 1998). In addition at Gannet Islands, males of both thick-billed murres and razorbills seem to be more aggressive and protective of their chicks than females (Paredes \& Insley, in 
prep.). Ainley et al. (2002) suggested that in common murres, males depart with the chick because of their slightly larger size and apparently more aggressive behaviour; however, few data have been reported so far. Altogether these results suggest a male-biased capability of defending the offspring at nest departure, and partly could explain why the male accompanies the chick at sea.

Another explanation for the partitioning of roles between sexes, although not mutually exclusive, is that the male goes to sea as a default of the female's choice of staying behind. One pair member seems to be required to stay at the colony to maintain the breeding site for the following season (Harris et al., 1996). Maintenance of the breeding site is crucial because if lost, it is likely that individuals will not breed the following year (Harris et al., 1996). In all our study pairs, males left the colony with the chick and females stayed at the breeding site. It has been suggested females stayed at the breeding site for mating with other males to ensure future reproductions in case of mate loss or poor quality partner (Gaston \& Jones, 1998). However, although females can copulate and form temporary bonds with other males these do not persist to the next season, even when the original males did not return (Harris \& Wanless, 2003). Thus, there is no support for female looking for replacement mates in case of widowing, but toward the female role of guarding the breeding site after male departure.

Both, escorting the chick at sea and guarding the breeding site after chick departure may require an aggressive sex. Nevertheless, a successful chick departure and fledging at sea is crucial for the fitness of both parents. Hence, a higher level of aggressiveness of the parent that escorts the chick to sea may have been selected for to ensure offspring survival. As a result, male parental role towards egg and chick defence (male-biased capability) and brooding (parent-offspring vocal recognition) might have developed at the breeding site at the same time or independently to ensure male-only care at sea.

\section{Acknowledgements}

We are grateful to Bobby Fokidis, Andy Higdon, Tony Lavictoire, Robert Eveleigh, Mark Button, Brian Veitch and Johanne Dussureault, for assistance in the field, and to Randy Cahill for logistic support. We benefited from discussions and comments on manuscript drafts from Stephen Insley, and David Schneider. We thank Steve Carr and Dawn Marshall for invaluable assistance and use of their laboratory for the genetic sexing. This study was supported by a CIDA fellowship to RP, the Atlantic Cooperative Wildlife Ecology Research Network 
CWS/NSERC Industrial Research Chair and NSERC Individual Research grants to ILJ, and by the Northern Scientific Training Program of the Department of Indian Affairs and Northern Development, Canada.

\section{References}

Ainley, D.G., Nettleship, D.N., Carter, H.R. \& Storey, A.E. (2002). Common murre Uria aalge. - In: The birds of North America no. 666 (Poole, A. \& Gill, F., eds), Academy of Sciences, Philadelphia, PA.

Bart, J. \& Tornes, A. (1989). Importance of monogamous male birds in determining reproductive success. - Behav. Ecol. Sociobiol. 18: 199-206.

Bédard, J. (1969). Historie naturelle du gode, Alca torda L., dans le golfe Saint-Laurent, province de Québec, Canada [Natural history of the razorbill, Alca torda, in the Gulf of the St. Lawrence, Québec, Canada]. - Étud. Serv. Can. no. 7, Otawa, ON.

Bech, C., Langseth, I., Moe, B., Fyhn, N. \& Grabrielsen, G.W. (2002). The energy economy of the arctic-breeding kitiwake (Rissa tridactyla): a review. - Comp. Biochem. Physiol., A. 133: 765-770.

Benvenuti, S., Bonadonna, F., Dall' Antonia, L. \& Gudmunsson, G.A. (1998). Foraging flights of breeding thick-billed murres (Uria lomvia) as revealed by bird-borne direction recorders. - Auk 115: 57-66.

Benvenuti, S., Dall' Antonia, L. \& Falk, K. (2002). Diving behaviour differs between incubating and brooding Brunnich's guillemots, Uria lomvia. — Polar Biol. 25: 474-478.

Birkhead, T.R. (1978). Behavioral adaptations to high density breeding siteing on the Common guillemot (Uria aalge). - Anim. Behav. 26: 321-331.

Birkhead, T.R. (1985). Coloniality and social behaviour in the Atlantic Alcidae. - In: The Atlantic Alcidae (Nettleship, D.N. \& Birkhead, T.R., eds). Academic Press, London, p. 355-383.

Birt-Friesen, V.L., Montevecchi, W.A., Cairns, D.K. \& Macko, S.A. (1989). Activity-specific metabolic rates of free-living northern gannets and other seabirds. — Ecology 70: 357367.

Burger, J. (1981). Sexual differences in parental activities in breeding black skimmers. Am. Nat. 117: 975-984.

Cairns, D.K. \& Schneider, D.C. (1990). Alcid patchiness and flight direction near a colony in eastern Newfoundland. - Avian Biol. 14: 23-35.

Chappel, M.A., Shoemaker, V.H., Janes, F.N. \& Bucher, T.L. (1993). Diving behavior during foraging in breeding Adelie penguins. - Ecology 74: 1204-1215.

Clode, D. (1993). Colonially breeding seabirds: predators or prey? — Trends Ecol. Evol. 8: 336-338.

Cody, M.L. (1971). Ecological aspects of reproduction. — In: Avian biology (Farner, D.S. \& King, J.R., eds). Academic Press, New York and London, p. 461-512.

Cramp, S. (1985). The birds of the western Paleartic. — In: Vol. 4: terns to woodpeckers. Oxford Univ. Press, Oxford, UK.

Croxall, J.P. \& Rothery, P. (1991). Population regulation of seabirds implications of their demography for conservation. - In: bird population studies: Relevance to conservation and management (Perrins, C.J., Lebreton, J.-D. \& Hirons, G.J.M., eds). Oxford University Press, Oxford, p. 272-296. 
Davoren, G.K., Montevecchi, W.A. \& Anderson, J.T. (2003). Search strategies of a pursuitdiving marine bird and the persistence of prey patches. - Ecol. Monogr. 73: 463-481.

Fowler, G.S. (1995). Stages of age-related reproductive sucess in birds: Simultaneous effects of age, pair-bond duration and reproductive experience. - American Zool. 35: 318-328.

Fraser, G.S., Jones, I.L. \& Hunter, F.M. (2002). Male-female differences in parental care in monogamous crested auklets (Aethia cristatella). - Condor 104: 413-423.

Fridolfsson, A.-K. \& Ellegren, H. (1999). A simple and universal method for molecular sexing of non-ratite birds. - J. Avian Biol. 30: 116-121.

Gaston, A.J. (1985). Energy invested in reproduction by thick-billed murres (Uria lomvia). Auk 102: 447-458.

Gaston, A.J. \& Jones, I.L. (1998). The Auks: Alcidae. — Oxford University Press, Oxford.

Gaston, A.J. \& Hipfner, M.J. (2000). Thick-billed murre. — In: The birds of North America, no. 497 (Poole, A. \& Gill, F., eds). Academy of Sciences, Philadelphia, PA.

Gaston, A.J. \& Nettleship, D.N. (1981). The thick-billed murres of Prince Leopold Island. Canadian Wildlife service Monographs no. 6. Canadian Wildlife Service, Otawa.

Gilchrist, H.G. \& Gaston, A.J. (1997). Factors affecting the success of colony departure by thick-billed murre chicks. - Condor 99: 345-352.

Gratto-Trevor, C.L. (1991). Parental care in semipalmated sandpipers Calidris pusilla: brood desertion by females. - Ibis 133: 394-399.

Granadeiro, J.P., Burns, M.D. \& Furness, R.W. (1999). Food provisioning to nestlings shearwaters, why parental behaviour should be monitored. - Anim. Behav. 57: 663-671.

Greenwalt, C.H. (1962). Dimensional relationships for flying animals. - Smithsonian Miscellaneous Collections, 144.

Harding, A., Van Pelt, T.I., Lifjeld, J.T. \& Mehlum, F. (2004). Sex differences in little auk (Alle alle) parental care: transition from biparental to paternal-only care. — Ibis 146 642-651.

Harris, M.P. (1983). Parent-young communication in the puffin Fratercula arctica. - Ibis 125: 109-114.

Harris, M.P., Halley, D. \& Wanless, S. (1996). Philopatry in the common guillemot Uria aalge. - Bird study 43: 134-137.

Harris, M.P. \& Wanless, S. (2003). Postfledging occupancy of breeding sites by female common murres (Uria aalge). - Auk 120: 75-81

Hipfner, J.M. \& Chapdelaine, G. (2002). Razorbill Alca torda. — In: The birds of North America no. 635 (Poole, A. \& Gill, F., eds). Academy of Sciences, Philadelphia, PA.

Houston, A.I. \& Davies, N.B. (1985). The evolution of cooperation and life history in the dunnock Prunela modularis. - In: Behavioral ecology (Sibly, R.M. \& Smith, R.H., eds). Oxford: Blackwell Scientific, p. 471-487.

Houston, A.I., Thompson, W.A. \& Gaston, A.J. (1996). The use of a time and energy budget model of a parent bird to investigate limits to fledging mass in the thick-billed murre. Funct. Ecol. 10: 432-439.

Ingold, P. (1973). Zur lautlichen Beziehung des Elters zu seinem Kueken bei Tordalken (Alca torda). - Behaviour 45: 154-190.

Insley, S.J., Paredes, R. \& Jones, I.L. (2003). Sex differences in razorbill Alca torda parentoffspring vocal recognition. - J. Exp. Biol. 206: 25-31.

Jodice, P.G.R., Roby, D.D., Suryan, R.M., Irons, D.B., Kaufman, A.M., Turco, K.R. \& Visser, G.H. (2003). Variation in energy expenditure among black-legged kittiwakes: Effects of activity-specific metabolic rates and activity budgets. - Physiol. Biochem. Zool. 76: 375-388. 
Jones, I.L., Falls, J.B. \& Gaston, A.J. (1987). Vocal recognition between parents and young of Ancient murrelets, Synthliboruramphus antiquus (Aves: Alcidae). - Anim. Behav. 35: 1405-1415.

Jones, I.L., Rowe, S., Carr, S.M., Fraser, G. \& Taylor, P. (2002). Different patterns of parental effort during chick-rearing by female and male thick-billed mures (Uria lomvia) at a low-arctic colony. — Auk 119: 1064-1074.

Jones, K.M., Ruxton, G.D. \& Monaghan, P. (2002). Model parents: is full compensation for reduced partner nest attendance compatible with stable biparental care? - Behav. Ecology 13: 838-843.

Lefevre, K., Montgomerie, R. \& Gaston, A.J. (1998). Parent-offspring recognition in thickbilled murres (aves: Alcidae). — Anim. Behav. 55: 925-938.

Maynard Smith, J. (1977). Parental investment: A prospective analysis. - Anim. Behav. 25 $1-9$.

Markman, S., Pinshow, B., Wright, J. \& Kotler, B.P. (2004). Food patch use by parents birds: to gather food for themselves or for their chicks?. - J. Anim. Ecol. 73: 747-755.

McNamara, J.M., Gasson, C.E. \& Houston, A.I. (1999). Incorporating rules for responding into evolutionary games. - Nature 401: 368-371.

Mehlum, F., Watanuki, Y. \& Takashaki, A. (2001). Diving behaviour and foraging habitats of Brunnich's guillemots (Uria lomvia) breeding in the high-arctic. - J. Zool. 255: 413-423.

Mock, D.W. \& Fujioka, M. (1990). Monogamy and long-term pair bonding in vertebrates. Trends in Ecol. Evol. 5: 39-43.

Nelson, J.B. (1978). The gannet. — Buteo Books, Vermillion, North Dakota.

Norderhaug, M. (1980). Breeding biology of the little auk (Plautus alle) in Svalbard. Norks — Polarinstitutt Skrifter nr. 173.

Obst, B.S. \& Nagy, K.A. (1992). Field energy expenditure of the southern giant-petrel. Condor 94: 801-810.

Orians, G.H. \& Pearson, N.E. (1979). On the theory of central place foraging. - In: Analysis of ecological systems (Horn, D.J., Mitchell, R.D. \& Stairs, G.R., eds). Ohio State University Press, Columbus, Ohio, p. 154-177.

Paredes, R., Jones, I.L. \& Boness, D.J. (2005). Reduced parental care, compensatory behaviour and reproductive costs experienced by female and male thick-billed murres (Uria lomvia) equipped with data loggers. - Anim. Behav. 69: 197-208.

Payne, L.X. \& Pierce, E.P. (2002). Purple sandpiper (Calidris maritima). — In: The birds of North America, no. 706 (Poole, A. \& Gill, F., eds). Academy of Sciences, Philadelphia, p. 1-36.

Piersma, T.A. (1996a). Family Scolopacidae (sandpipers, snipes and phalaropes). - In: Handbook of the birds of the world, vol. 3. Hoatzin to auks (del Hoyo, J., Elliott, A. \& Sargatal, J., eds). Lynx Edicions, Barcelona, Spain, p. 444-487.

Piersma, T.A. (1996b). Family Charadriidae (plovers). - In: Handbook of the birds of the world, vol. 3. Hoatzin to auks (del Hoyo, J., Elliott, A. \& Sargatal, J., eds). Lynx Edicions, Barcelona, Spain, p. 384-409.

Schneider, D.C., Pierotti, R. \& Threlfall, W. (1990). Alcid patchiness and flight direction near a colony in eastern Newfoundland. - Avian Biol. 14: 23-35.

Sealy, S.G. (1973). Adaptive significance of post-hatching developmental patterns and growth rates in the Alcidae. — Ornis Scand. 4: 113-121. 
Spear, L.B. \& Ainley, D.G. (1997). Flight speed of seabirds in relation to wind speed and direction. - Ibis 139: 234-251.

Stempniewicz, L. (1995). Predator-prey interactions between Glaucous Gull Larus hyperboreus and Little Auk Alle alle at Spitsbergen. - Acta Ornithol. 29: 155-170.

Stempniewicz, L. (2001). Little auk Alle alle. - BWP Update 3: 175-201.

Stearns, S.C. (1992). The evolution of life histories. — Oxford University Press, New York.

Tershy, R.B. \& Croll, A.D. (2000). Parental investment, adult sex ratios, and sexual selection in a socially monogamous seabird. - Behav. Ecol. Sociobiol. 48: 52-60.

Trivers, R.L. (1972). Parental investment and sexual selection. - In: Sexual selection and the descent Man (Campbell, E.D., ed.). Aldine Press, Chicago: 136-179.

Verspoor, E., Birkhead, T.R. \& Nettleship, D.N. (1987). Incubation and brooding shift duration in the common murre, Uria aalge. — Can. J. Zool. 65: 247-252.

Wagner, R.H. (1992). The pursuit of extra-pair copulations by monogamous female Razorbills: how do females benefit? — Behav. Ecol. Sociobiol. 29: 455-464.

Wagner, R.H. (1999). Sexual size dimorphism and assertive mating in razorbills (Alca torda). - Auk 116: 542-544.

Wanless, S. \& Harris, M.P. (1986). Time spent at the colony by male and female guillemots Uria aalge and razorbills Alca torda. - Bird Study 33: 168-176.

Wilhelm, S.I. (2004). Behavioural and physiological responses of breeding common murres (Uria aalge): exploring inter-annual variability among individuals. $-\mathrm{PhD}$ thesis, Memorial University of Newfoundland, Canada.

Williams, G.C. (1966). Natural selection, the costs of reproduction and a refinement of Lack's principle. - Am. Nat. 100: 687-690.

Woller, R.D., Bradley, J.S. \& Croxall, J.P. (1992). Long-term population studies of seabirds. - Trends Ecol. Evol. 7: 111-114.

Ydenberg, R.C. (1989). Growth-mortality trade-offs and juvenile life history in the alcidae. Ecology 70: 1494-1506.

Ydenberg, R.C., Clark, C.W. \& Harfenist, A. (1995). Intraspecific fledging mass variation in the Alcidae family, with special reference to the seasonal fledging mass decline. - Am. Nat. 145: 412-433. 